\title{
BASE FLOW OF STREAMS IN THE OUTCROP AREA OF SOUTHEASTERN SAND AQUIFER: South Carolina, Georgia, Alabama, and Mississippi
}

BY

VIRGINIA A. STRICKER

U.S. GEOLOGICAL SURVEY

WATER-RESOURCES INVESTIGATIONS 83-4106

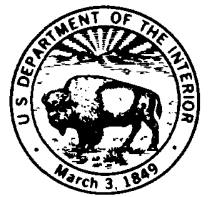

October 1983 


\title{
UNITED STATES DEPARTMENT OF THE INTERIOR
}

\author{
JAMES G. WATT, SECRETARY
}

\section{GEOLOGICAL SURVEY}

\author{
Dallas L. Peck, Director
}

For additional information write to:

Regional Hydrologist

U.S. Geological Survey

Richard B. Russell Federal Building

75 Spring Street, S. W., Suite 772

Atlanta, Georgia 30303
Copies of this report can be purchased from:

Open-File Services Section

Western Distribution Branch

U.S. Geological Survey

Box 25425, Federal Center

Denver, Colorado 80225

Telephone: (303) 234-5888 


\section{CONTENTS}

Page

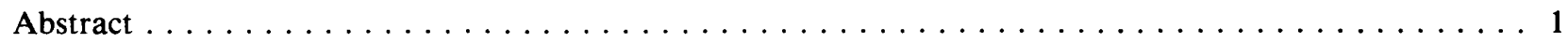

Introduction $\ldots \ldots \ldots \ldots \ldots \ldots \ldots \ldots \ldots \ldots \ldots \ldots \ldots \ldots \ldots \ldots \ldots \ldots \ldots \ldots \ldots \ldots$

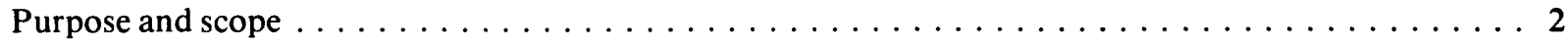

Geologic and hydrologic setting $\ldots \ldots \ldots \ldots \ldots \ldots \ldots \ldots \ldots \ldots \ldots \ldots \ldots \ldots \ldots \ldots$

Method of investigation $\ldots \ldots \ldots \ldots \ldots \ldots \ldots \ldots \ldots \ldots \ldots \ldots \ldots \ldots \ldots \ldots$

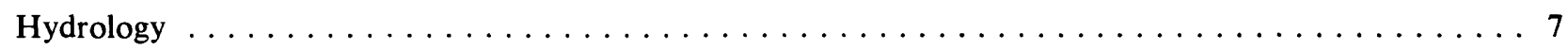

Relation of base flow to flow duration $\ldots \ldots \ldots \ldots \ldots \ldots \ldots \ldots \ldots \ldots \ldots$

Relation of streamflow to ground-water discharge $\ldots \ldots \ldots \ldots \ldots \ldots \ldots \ldots \ldots \ldots \ldots \ldots$

Effect of aquifer lithology on flow duration of streams $\ldots \ldots \ldots \ldots \ldots \ldots \ldots \ldots \ldots \ldots$

Estimating hydraulic properties of the aquifer $\ldots \ldots \ldots \ldots \ldots \ldots \ldots \ldots \ldots \ldots \ldots \ldots$

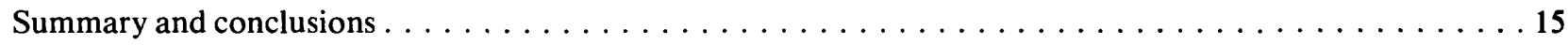

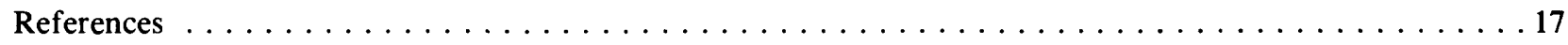

\section{ILLUSTRATIONS}

Figure 1. Diagram showing components of water balance equation $\ldots \ldots \ldots \ldots \ldots \ldots \ldots \ldots$

2. Map showing location of streamflow gaging stations $\ldots \ldots \ldots \ldots \ldots \ldots \ldots \ldots$

3. Graph showing synthesis of base flow recession curve for

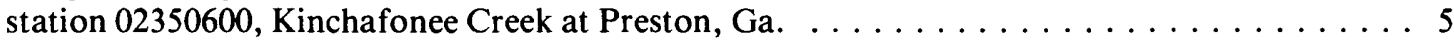

4. Graph showing master base flow recession for station 02350600 ,

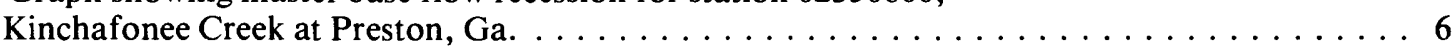

5. Diagram showing discharge hydrograph showing base-runoff separation, station 02350600, Kinchafonee Creek at Preston Ga., 1967 water year . . . . . . . . . . . 6

6. Map showing mean annual base flow values by drainage basin $\ldots \ldots \ldots \ldots \ldots \ldots$

7-10. Graphs showing:

7. Flow duration curves for station 02197300 , Upper Three Runs near New Ellenton, S.C., and station 02422000, Big Swamp Creek near Lowndesburg, Ala.

8. Comparison of mean annual base flow values and discharge at 65-percent duration point .

9. Comparison of mean annual base flow values and discharge at

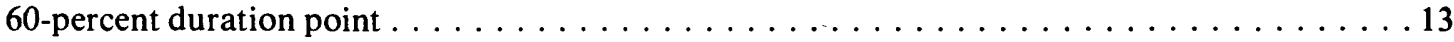

10. Comparison of flow duration index to percent of total streamflow that is baseflow 


\section{TABLES}

Table 1. Mean annual base flow for basins in the sand aquifer

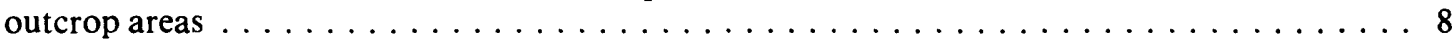

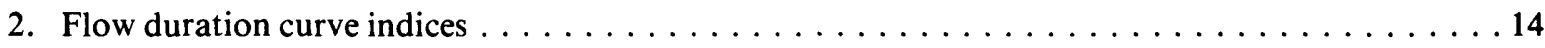

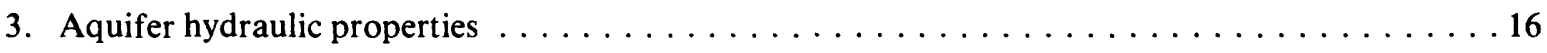




\section{BASE FLOW OF STREAMS IN THE OUTCROP AREA OF SOUTHEASTERN SAND AQUIFER: South Carolina, Georgia, Alabama, and Mississippi}

BY

VIRGINIA A. STRICKER

\begin{abstract}
The base flow component of streamflow was separated from streamflow hydrographs of unregulated streams in the Cretaceous and Tertiary clastic outcrop area of South Carolina, Georgia, Alabama, and Mississippi. Relations developed between mean annual base flow and stream discharge at the 60- and 65-percent streamflow duration point can be used to approximate mean annual base flow in lieu of hydrograph separation methods for mean base flows greater than $10 \mathrm{ft}^{3} / \mathrm{s}$. The base flow values are used in estimating recharge to the sand aquifer.
\end{abstract}

Base flow recession curves were used to derive estimates of hydraulic diffusivity of the aquifer which was converted to transmissivity using estimated specific yield. These base flow derived transmissivities are in general agreement with transmissivities calculated from well data.

The shape of flow duration curves of streams is affected by the lithology of the Coastal Plain sediments. Steep flow duration curves are associated with basins underlain by clay or chalk where a low percentage of the discharge is base flow whereas flatter curves are associated with basins underlain by sand and gravel where a high percentage of the discharge is base flow.

\section{INTRODUCTION}

The U.S. Geological Survey is developing a large-scale digital ground-water flow model of the sand aquifer system of the Southeastern Coastal Plain of the United States. The model will provide a better understanding of the freshwater flow system of the Cretaceous and associated Tertiary sand aquifers and should be useful for water-management purposes. In order to properly calibrate the model, data are needed on the rate and location of recharge to the aquifers. If the rate of leakage to rivers from the aquifer in the outcrop area is known, estimates of recharge rate to the aquifer can be made with water balance equations. The applicable water balance equations (components of equation illustrated in figure 1) are:

$\mathbf{R}_{\mathrm{s}}=\mathrm{P}-\mathrm{ET}-\mathrm{RO}$

$\mathbf{R}_{\mathrm{s}}=\mathrm{BF}+\mathbf{R}_{\mathrm{D}}$

where:

$$
\begin{aligned}
& R_{\mathrm{s}}=\text { shallow recharge, in in } / \mathrm{yr}, \\
& \mathrm{P}=\text { precipitation, in in/yr, } \\
& \mathrm{ET}=\text { evapotranspiration, in in/yr, }
\end{aligned}
$$




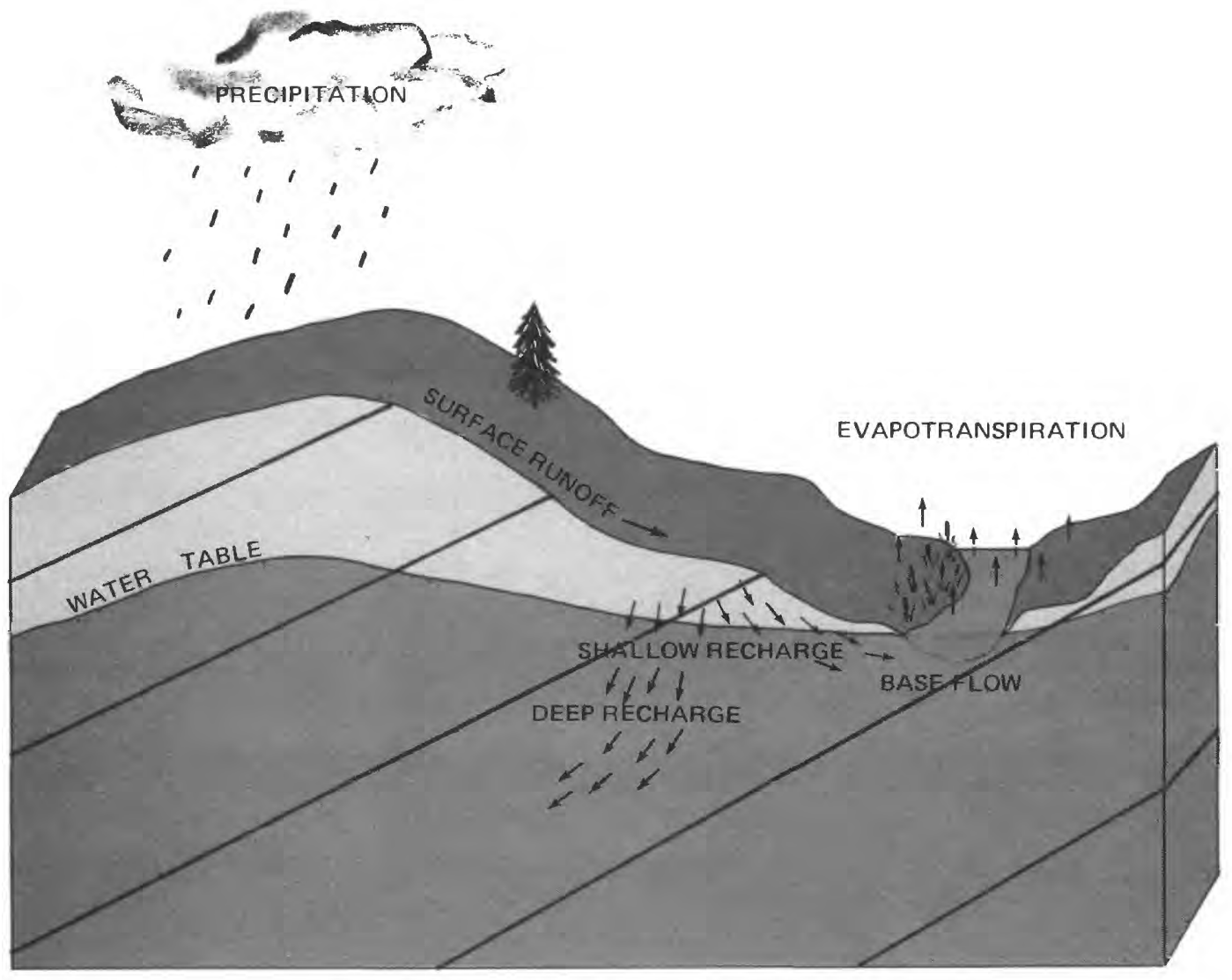

Figure 1. Components of water balance equation.

$\mathrm{RO}=$ runoff, in in $/ \mathrm{yr}$,

$\mathrm{BF}=$ base flow, in in $/ \mathrm{yr}$, and

$R_{D}=$ deep recharge, in in $/ y r$.

Shallow recharge is difficult to calculate from equation 1 because of the error in determining $\mathbf{P}$ and, especially, ET. However, once base flow is known, equation 2 can be used to estimate a minumum shallow recharge value. Deep recharge remains unknown at this point, but since deep recharge is so small in comparison to shallow recharge, shallow recharge must be nearly equal to base flow. Therefore, base flow provides a preliminary estimate for shallow recharge.

\section{Purpose and Scope}

The purposes of this study are to derive base flow estimates for representative parts of the Cretaceous and Tertiary clastic outcrop area as an aid in estimating recharge to the sand aquifers; to use base flow relations to estimate aquifer hydraulic parameters; and to relate the lithology of the aquifer to the streamflow duration curves. Twenty-nine gaging stations were chosen on streams with drainage basins located largely within the limits of the outcrop area. In addition, six stations (three upstreamdownstream pairs) in Georgia were chosen to isolate the outcrop area. The data base includes 10 sites in South Carolina, 10 sites in Georgia, 9 sites in Alabama, and 6 sites in Mississippi. The sites 
selected, together with the approximate limits of the Cretaceous and associated Tertiary outcrop, are shown in figure 2 .

\section{GEOLOGIC AND HYDROLOGIC SETTING}

The area of investigation is in the southeastern United States and includes part of the Coastal Plain in South Carolina, Georgia, Alabama, and Mississippi. The sand aquifer system consists of rocks predominately Cretaceous but that range in age from Cretaceous to Holocene. These rocks crop out in an area adjacent to the Fall Line and extending toward the Atlantic Ocean and Gulf of Mexico (fig. 2). The area of outcrop in South Carolina extends from the Fall Line near Columbia eastward almost to the Atlantic Ocean and in Georgia from the Fall Line southward in a band ranging from about 10 miles in width south of Augusta in the eastern part of the state to about 60 miles in width along the Chattahoochee River in the western part of the State. In Alabama and Mississippi, the outcrop area, about 50 to 60 miles wide, extends across the central part of Alabama and swings northward along the Alabama-Mississippi border. The sediments consist primarily of quartzose and glauconitic sands and gravel and interbedded clay, shale, or chalk layers. The sand and gravel beds are aquifers and the clay and chalk beds are confining beds.

Precipitation in the outcrop area averages 47 inches in South Carolina, 45 inches in Georgia, and 52 inches in Alabama and Mississsippi (from climatologic data for these states as listed under NOAA in references).

Streamflow includes both surface runoff, which flows over the land surface and into the stream during and immediately following a storm, and base flow, which is primarily discharge to the stream from ground-water sources (see fig. 1). Average annual streamflow is about 15 inches in South Carolina, slightly greater than 16 inches in Georgia, 18 inches in Alabama, and 22 inches in Mississippi. Base flow varies depending upon the geology of the watershed. In a basin underlain primarily by chalk having low permeability, the base flow component of streamflow is relatively small; but in a basin underlain primarily by sand, the base flow component is much higher.

\section{METHOD OF INVESTIGATION}

Annual streamflow hydrographs were analyzed for each of the 35 stations. Streams that were not regulated were chosen; however, if a stream is or was regulated, hydrographs were selected for periods prior, or subsequent, to the period of regulation. Within these limitations and in order to obtain representative samples of annual base flow values, hydrographs for each station were chosen where possible from years when the annual mean flow was higher than, lower than, and close to the average mean flow for the period of record.

Methods of separating base flow from streamflow hydrographs were then evaluated to determine the most appropriate method to use in this study. According to Hall (1968), hydrologists have studied base flow recession characteristics for 100 years or more. Generally, graphical or statistical methods have been followed rather than mathematical approaches primarily because of problems caused by the assumptions made and because of difficulties in interpreting the stream hydrograph.

The analysis used in this study is a method described by Riggs (1963) and uses base flow recession curves derived from segments of the streamflow hydrograph to determine annual base flow. Base flow recession curves are derived from segments of streamflow hydrographs from the lower end of the streamflow recession when streamflow is assumed to be virtually all base flow. For each segment, the discharges at the beginning day and on the 10th day, and every following 10th day are tabulated. The points, beginning day versus 10 th day, 10th day versus 20th day, and so on, are then plotted on a log-log scale. A curve fitted to the points (fig. 3) is used to prepare a master base flow recession (fig. 4) on semi-log paper with discharge on the log scale versus time on the rectilinear scale. The master recession relation is then used to sketch a hydrograph of base flow under the hydrograph of total flow. The procedure is illustrated with station 02350600, Kinchafonee Creek at Preston, Ga. (fig. 5). Here the base flow recession curve is used to sketch a hydrograph of base flow under the hydrograph of total flow for the 1967 water year. As is apparent in the figure, hydrograph separation using this method is of necessity somewhat subjective since the master base flow recession curve must be 


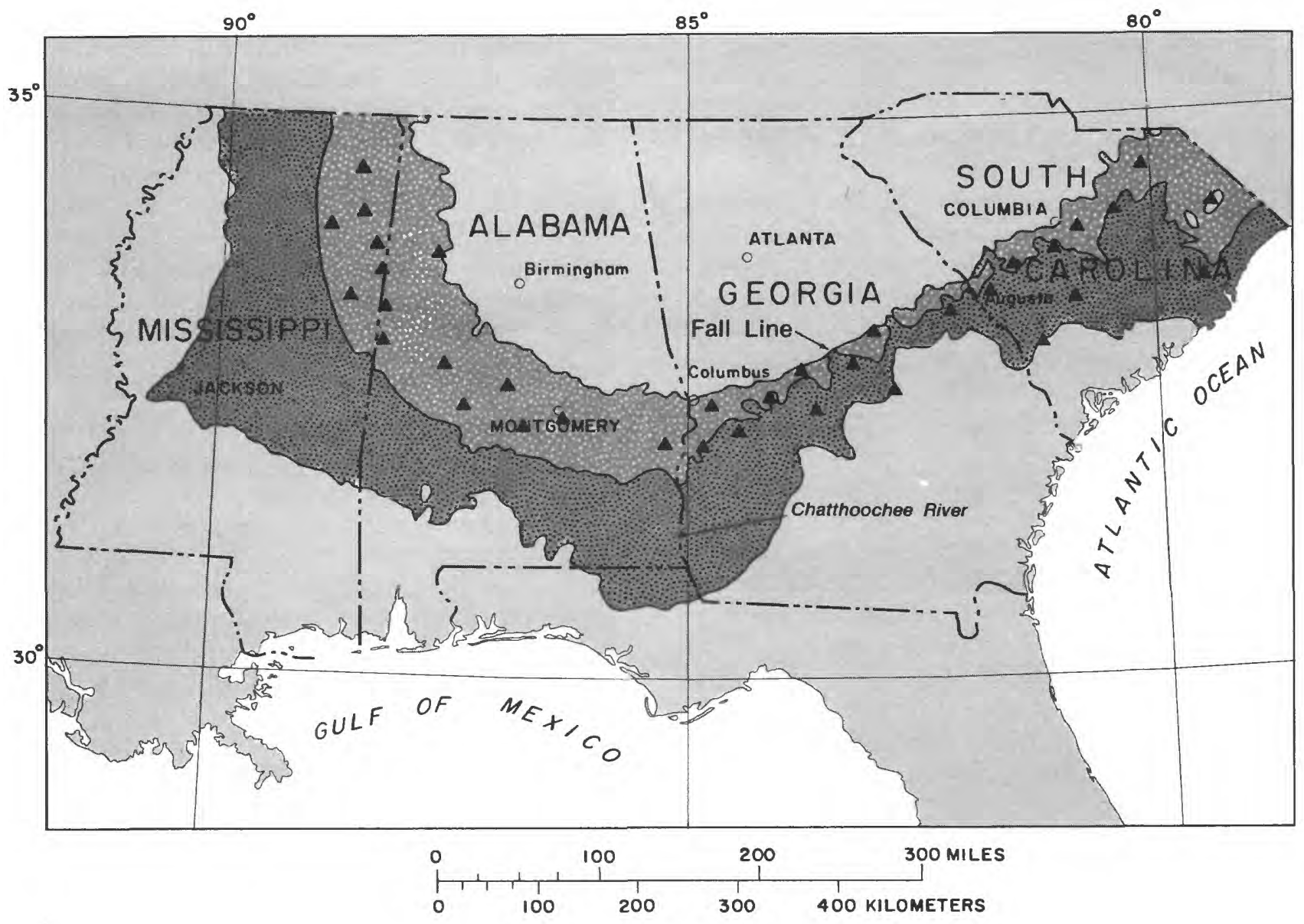

EXPLANATION

Streamflow gaging
station

C.9. Cretaceous outcrop

Lower Tertiary outcrop

Figure 2. Location of streamflow gaging stations. 


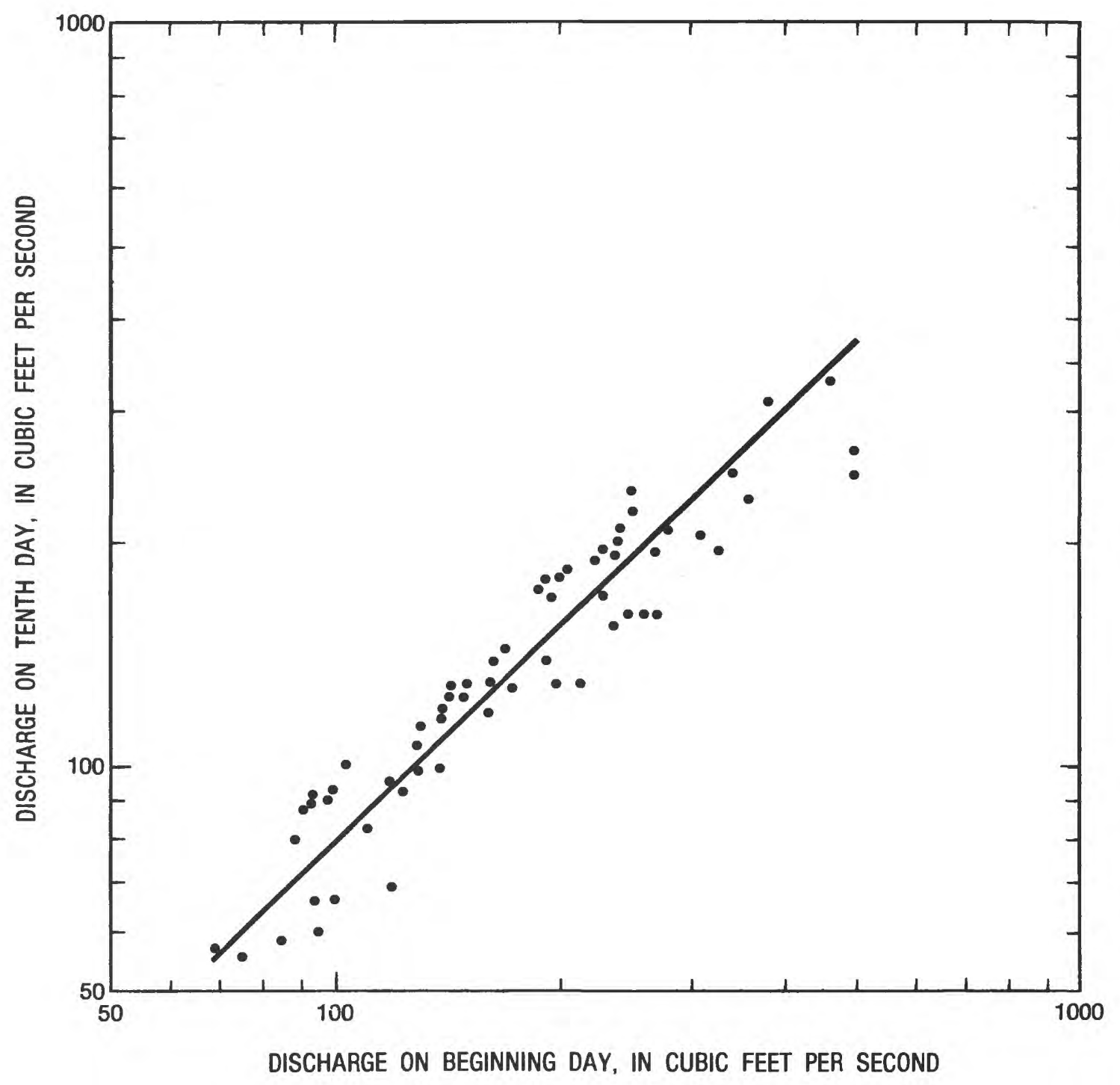

Figure 3. Synthesis of base flow recession curve for station 02350600 , Kinchafonee Creek at Preston, Ga. 


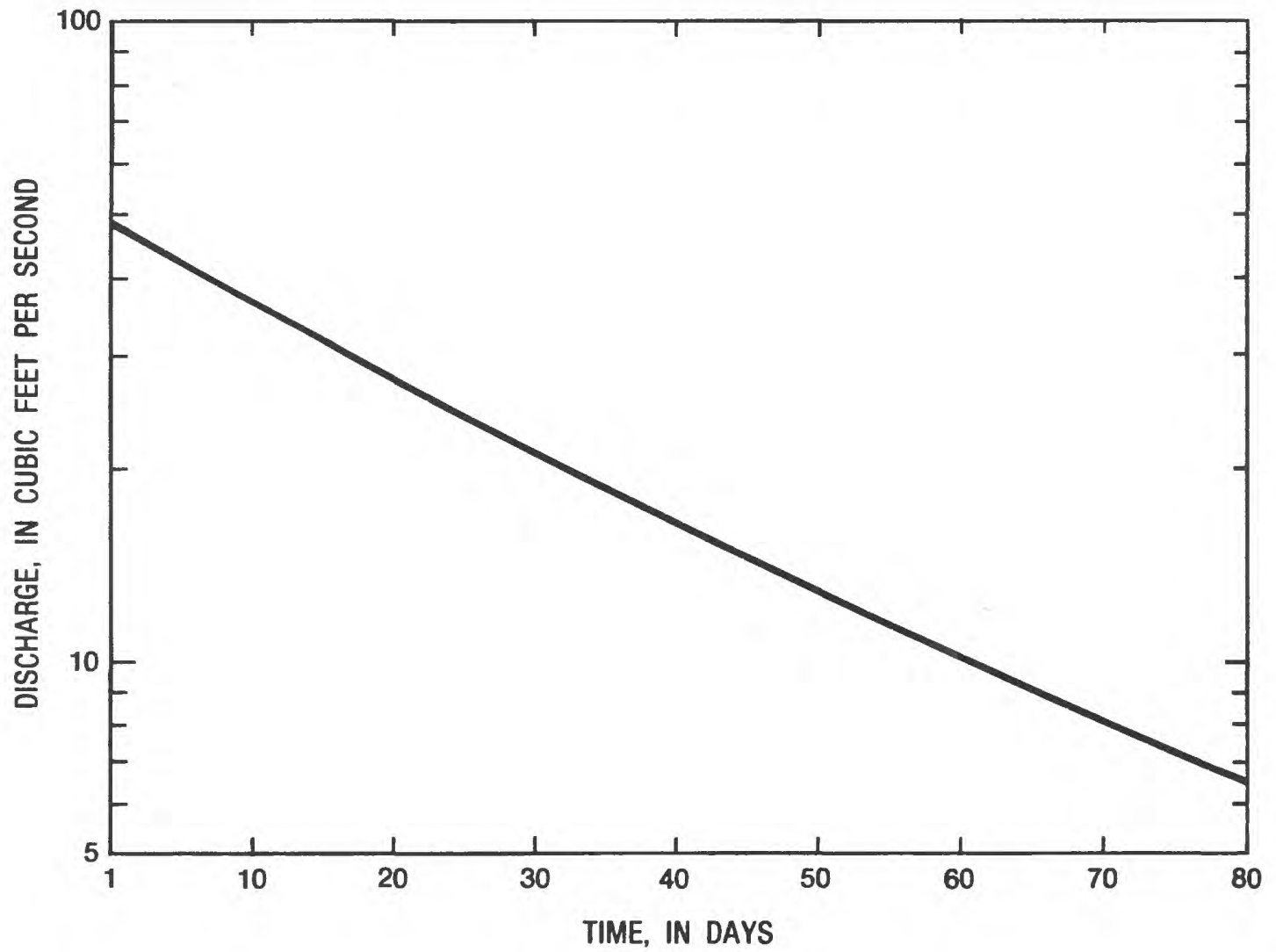

Figure 4. Master base flow recession curve for station 02350600 , Kinchafonee Creek at Preston, Ga.

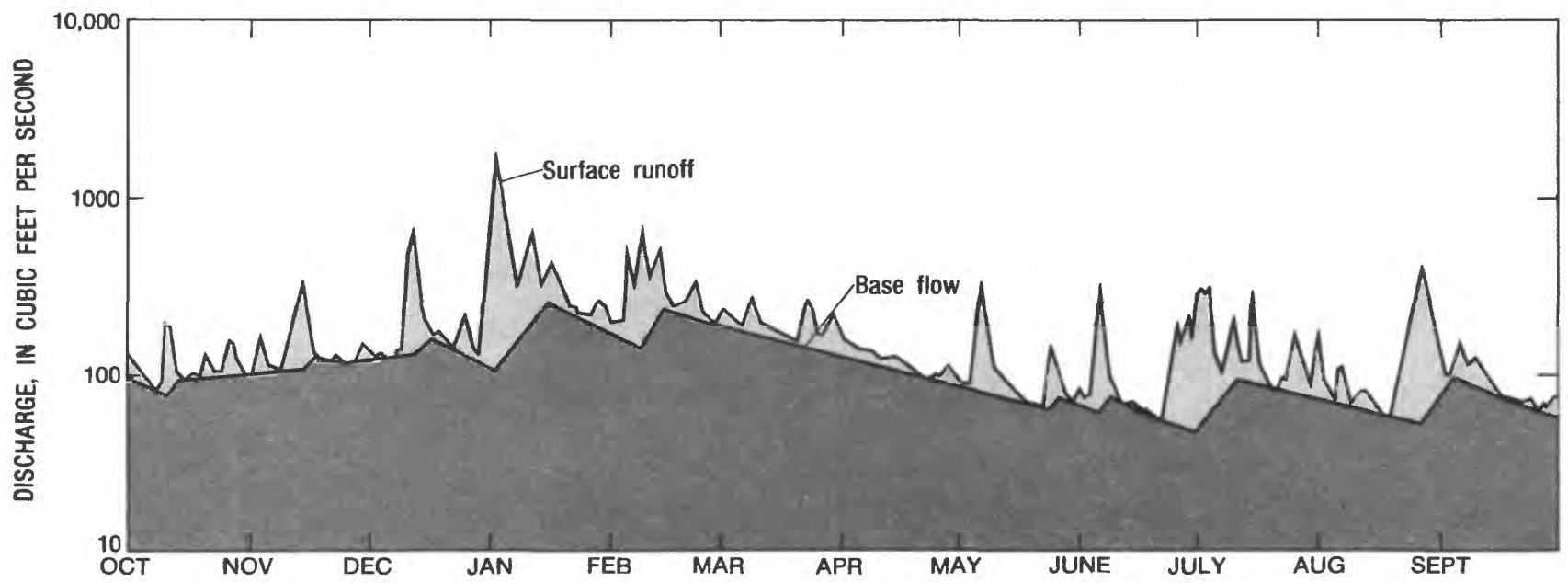

Figure 5. Discharge hydrograph showing base runoff separation, station 02350600 , Kinchafonee Creek at Preston, Ga., 1967 water year. 
adjusted at times to reflect changes in the slope of the recession.

These changes may be caused by the stream receiving ground-water discharge (base flow) from several aquifers, each aquifer having a different discharge characteristic (transmissivity) and each aquifer being recharged by precipitation at different rates and times. Furthermore, the aquifer or aquifers may lose water through ET (evapotranspiration) and the water discharged to the stream be subject to variable evapotranspiration withdrawals daily as well as seasonally. ET causes the recessions to be steeper in summer than winter. The base flow hydrographs derived from this method are, therefore, somewhat subjective but it is believed that for the purpose of input to a model of regional ground-water flow, the resulting estimates of annual base flow are reasonable. Hydrographs were separated for years when the annual mean flow was higher than, lower than, and close to the average mean flow for the period of record for each of the 35 stations. These values were then averaged to determine the mean annual base flow.

The mean annual base flow values for the 35 stations are shown on figure 6 and listed in table 1 . Included in table 1 are the base flow in percent of total runoff, mean annual base flow, the drainage area, and the period of record for each station. Base flows labeled "pickup" refer to those large streams having two gages available to isolate base flow within the outcrop area. For these streams the difference in base flow is used rather than the value which is applicable to the total watershed.

\section{HYDROLOGY}

\section{Relation of Base Flow to Flow Duration}

Base flow can be compared to the flow duration curve of a stream. The flow duration curve is a cumulative frequency curve that shows the percent of time during which specified discharges are equaled or exceeded in a given period. For example, from the flow duration curve in figure 7 for Big Swamp Creek near Lowndesburg, Ala., a discharge of $21 \mathrm{ft}^{3} / \mathrm{s}$ is equaled or exceeded 50 percent of the time; and from the flow duration curve for Upper Three Runs near New Ellenton, S.C., a discharge of $107 \mathrm{ft}^{3} / \mathrm{s}$ is equaled or exceeded 50 percent of the time. Cushing and others (1973) have shown on the Delmarva Peninsula that stream discharge at the 50-percent duration point (median flow) of streams is approximately equal to the mean annual base flow. Reynolds (1982) found on Long Island, N.Y., a close emperical relation between base flow and stream discharge at the 55-percent duration point. Pettyjohn and Henning (1979) indicate that in Ohio, base flow is in the 60- to 90-percent flow duration range depending upon the lithology of the basin.

To determine if a similar relation is applicable in the sand aquifer outcrop area, mean annual base flow at each station was related to the discharge falling between the 50- and 75-percent points on the annual flow-duration curve for each station. Discharge from the curve that most nearly equaled the mean annual base flow was that at the 65 -percent duration. Mean annual base flows for the 35 stations are plotted against their respective 65-percent duration point discharges in figure 8 .

The mean annual base flows for two points $A$ and B were deleted from the data set for purposes of regression analysis. It did not appear that the comparison was valid for these points possibly because the relation may not be applicable to streams where mean annual base flow is less than 10 $\mathrm{ft}^{3} / \mathrm{s}$. A third point, C, was deleted because of poor definition of base flow in hydrograph separation. Point $\mathrm{C}$ represents a drainage basin consisting mostly of chalk; therefore the base flow may be much lower than that calculated.

A linear regression through the remaining data points produced a regression line with a standard error of \pm 11.9 percent and whose equation is:

$$
\mathrm{BF}=1.17 \mathrm{Q}_{65}{ }^{0.96}
$$

where:

$$
\begin{aligned}
& \mathrm{BF}=\text { mean annual base flow in cubic feet per } \\
& \text { second, } \\
& \mathrm{Q}_{65}=65 \text {-percent duration flow from flow } \\
& \text { duration curve in cubic feet per second. }
\end{aligned}
$$


Table 1.--Mean annual base flow for basins in the sand aquifer outcrop areas.

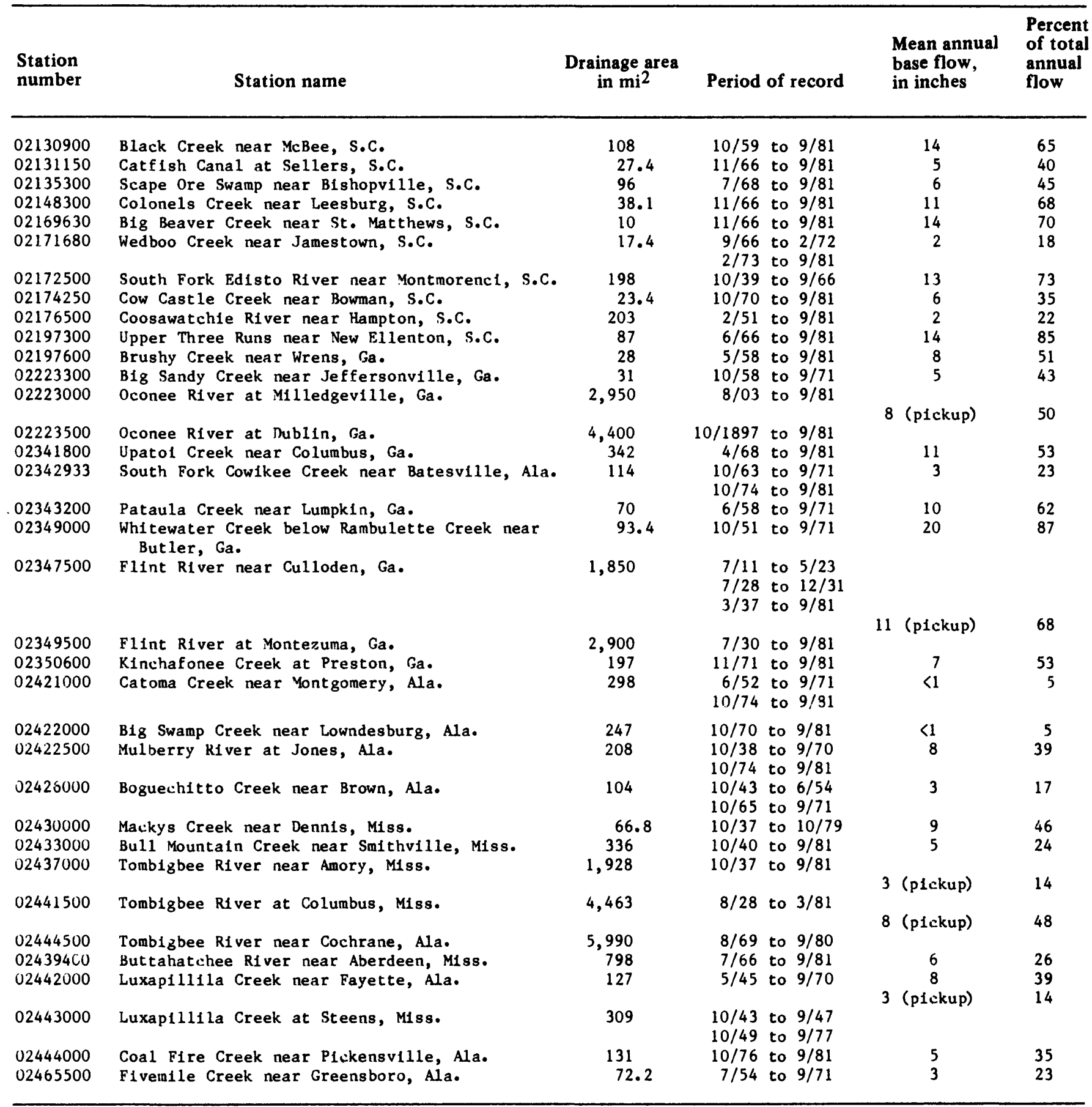




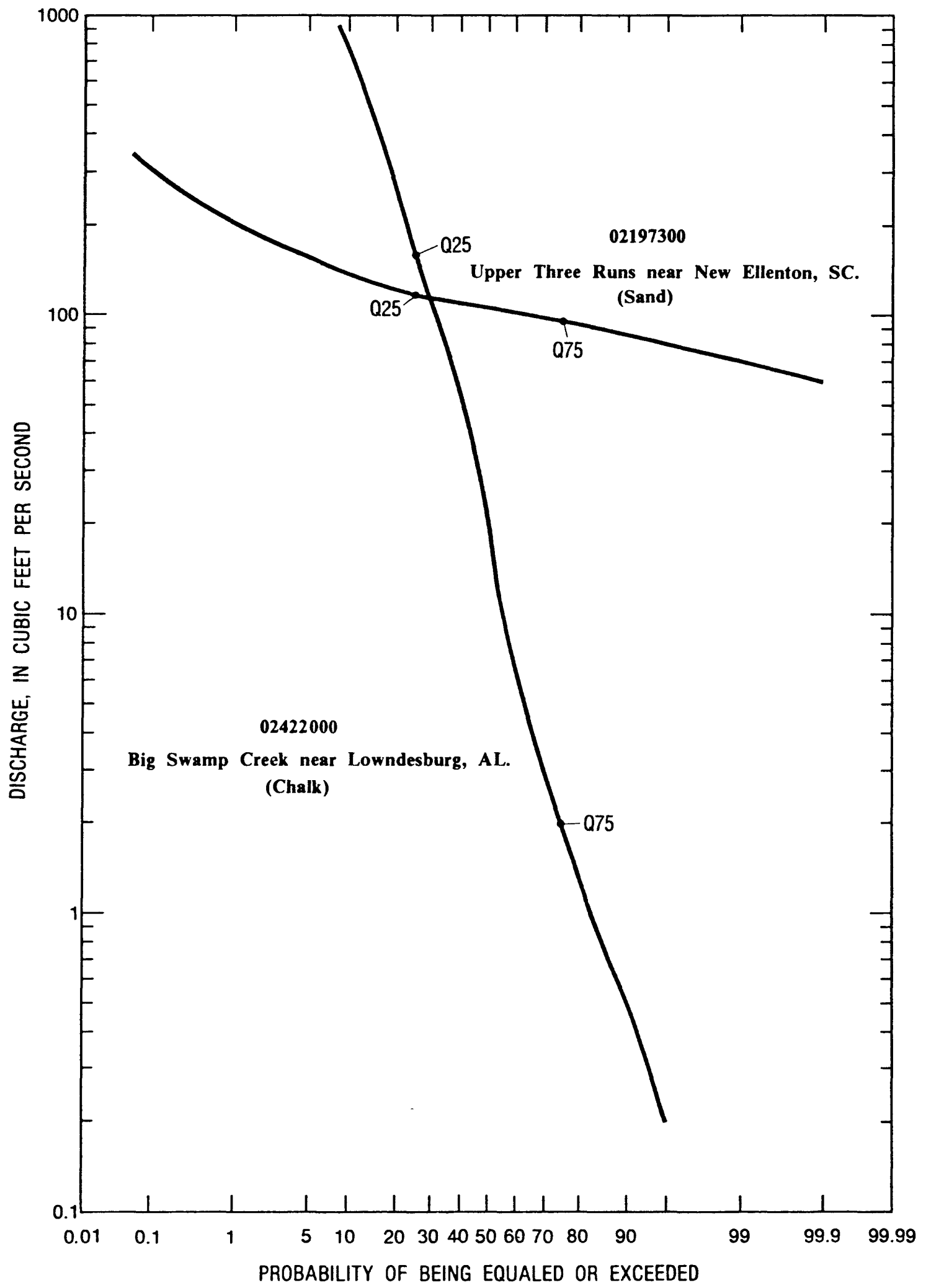

Figure 7. Flow-duration curves for station 02197300, Upper Three Runs near New Ellenton, S.C., and station 02422000, Big Swamp Creek near Lowndesburg, Ala. 


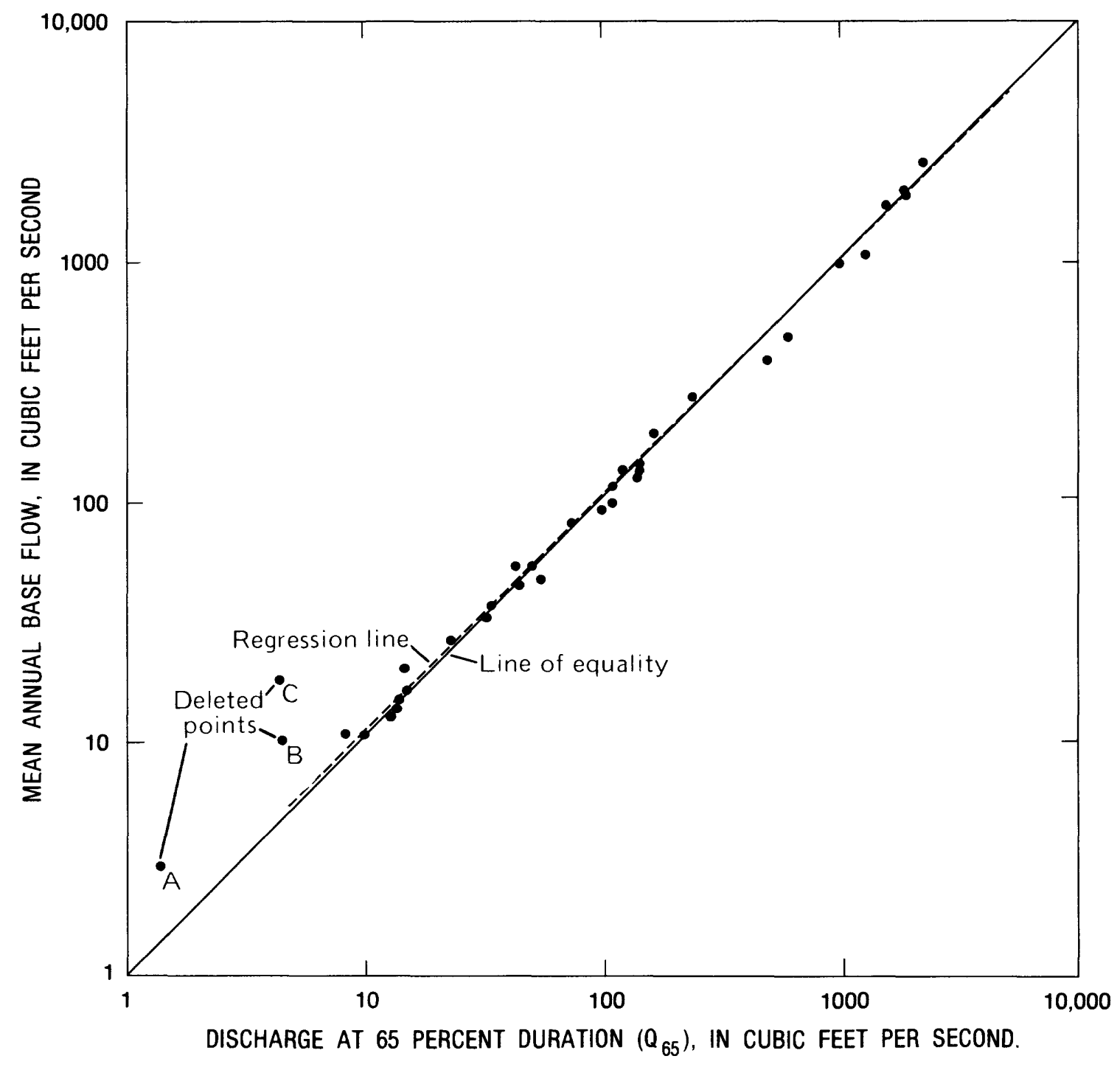

Figure 8. Comparison of mean annual base flow values and discharge at 65 -percent duration point. 
A close comparison was also noted between base flow through hydrograph separation and the 60-percent duration flow (fig. 9). A linear regression through the data points (again points $\mathrm{A}, \mathrm{B}$, and $\mathrm{C}$ were deleted) produced the regression line with a standard error of \pm 14.2 percent and whose equation is:

$\mathrm{BF}=1.01 \mathrm{Q}_{60}^{0.96}$

where:

$\mathrm{BF}=$ mean annual base flow in cubic feet per second,

$\mathrm{Q}_{60}=60$-percent duration flow from flow duration curve in cubic feet per second.

Based upon the regression results and an analysis of the graphical relations, it would appear that either the 60- or the 65-percent duration flow would give a reasonable estimate of the mean annual base flow for streams having mean base flows greater than $10 \mathrm{ft}^{3} / \mathrm{s}$. A closer estimate of base flow can be generated using equations 3 and 4 .

\section{Relation of Streamflow to Ground-Water Discharge}

\section{Effect of Aquifer Lithology on Flow Duration of Streams}

One index of the effect of geology on streamflow is in the shape of the flow duration curve. Several authors (Ackroyd and others, 1967; Pettyjohn and Henning, 1979) have noted that this shape is governed in part by the water yielding properties or ground-water storage potential of the basin. A stream is a basin component. Accordingly, a stream in a basin underlain by sand and gravel with good storage and water yielding properties will have a flatter flow duration curve than a stream in a basin underlain by clay which will store large volumes of water but does not yield it readily. Although caution should be used in interpreting the flow duration curve, usually the flatter the curve, the more ground-water storage available for release to streams in the basin. Conversely, the steeper the curve, the more flashy the stream indicating a smaller ground-water storage capacity available to the streams in the basin. Examples of a relatively flat and a steep curve are shown in figure 7. An index used to describe the shape of the curve is the ratio $\left(Q_{25} / Q_{75}\right)^{1 / 2}$ where $Q_{25}$ is the streamflow equaled or exceeded 25 percent of the time and $Q_{75}$ is the streamflow equaled or exceeded 75 percent of the time. Indices for 26 of the 35 basins studied are given in table 2 . Those stations isolating the outcrop area are not included because the ratio $\left(Q_{25} / Q_{75}\right)^{1 / 2}$ would not pertain to the isolated area. From the values given, the smallest index or the flattest curve is for station number 02197300, Upper Three Runs near New Ellenton, S.C., a station whose basin consists almost entirely of the Tertiary Barnwell Sand. The mean annual base flow for station 02197300 is 14 inches which is 85 percent of the total annual runoff (table 1). Ground-water runoff thus constitutes a large proportion of the flow for this basin. The highest ratio or the steepest curve is for station number 02422000, Big Swamp Creek near Lowndesburg, Ala., a station whose basin is underlain for the most part by Cretaceous Demopolis Chalk and Mooreville Chalk. The mean annual base flow for station 02422000 is less than 1 inch or only 5 percent of the total annual discharge (table 1). As is shown in figure 10 , there is generally an inverse relation between the index $\left(Q_{25} / Q_{75}\right)^{1 / 2}$ and base flow as a percentage of total annual runoff.

\section{Estimating Hydraulic Properties of the Aquifer}

The aquifer property hydraulic diffusivity is defined as the transmissivity $(T)$ divided by the storage coefficient (S) and can be estimated from the base flow recession slope using the following equation presented by Rorabaugh (1960):

$\mathrm{T} / \mathrm{S}=\left(0.933 \mathrm{a}^{2}\right) / \mathrm{t}$

where:

$\mathrm{T} / \mathrm{S}=$ hydraulic diffusivity, $\left(\mathrm{L}^{2 / \mathrm{t}}\right)$

$a=$ average distance to the ground-water divide from the stream, $(\mathrm{L})$ and

$t=$ number of days required for the recession to recede through one log cycle. $(\mathrm{t})$

Rorabaugh's equation is based upon the assumption that the permeability and aquifer thickness do not vary with time or place. The sand aquifer model is constructed assuming transmissivity is constant because when considered over the long term, the head (water level) fluctuations result in only minor variations in transmissivity. 


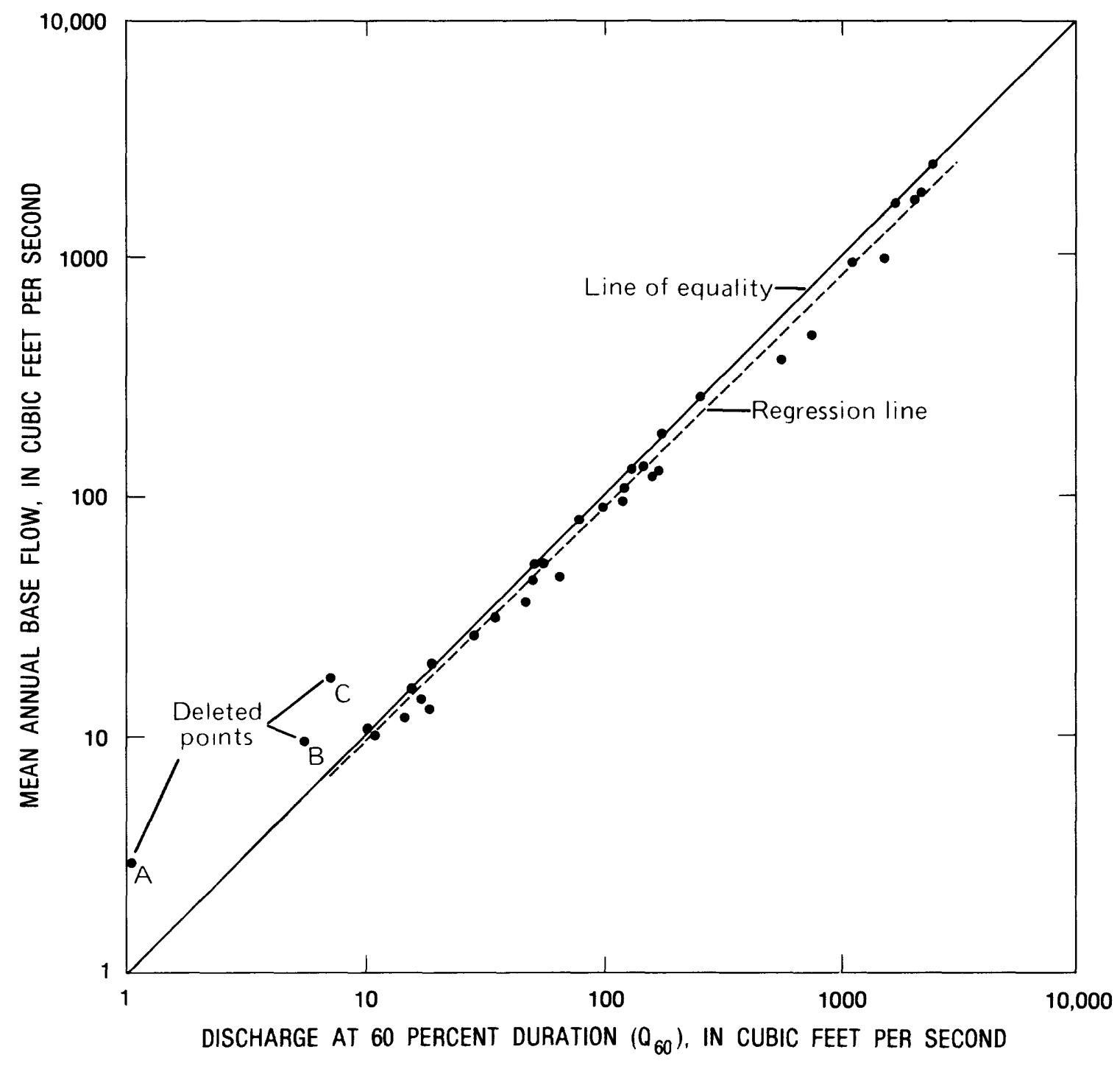

Figure 9. Comparison of mean annual base flow values and discharge at 60-percent duration point. 
Table 2.--Flow duration curve indices.

\begin{tabular}{|c|c|c|c|}
\hline $\begin{array}{l}\text { Station } \\
\text { number }\end{array}$ & Station name & $\left(Q_{25} / Q_{75}\right)^{1 / 2}$ & Prominent lithology \\
\hline $\begin{array}{l}02130900 \\
02131150 \\
02135300 \\
02148300 \\
02169630 \\
02171680 \\
02172500 \\
02174250 \\
02176500 \\
02197300 \\
02197600 \\
02223300 \\
02341800 \\
02342933 \\
02343200 \\
02349000\end{array}$ & $\begin{array}{l}\text { Black Creek near McBee, S.C. } \\
\text { Catfish Canal at Sellers, S.C. } \\
\text { Scape Ore Swamp near Bishopville, S.C. } \\
\text { Colonels Creek near Leesburg, S.C. } \\
\text { Big Beaver Creek near St. Matthews, S.C. } \\
\text { Wedboo Creek near Jamestown, S.C. } \\
\text { South Fork Edisto River near Montmorenci, S.C. } \\
\text { Cow Castle Creek near Bowman, S.C. } \\
\text { Coosawatchie River near Hampton, S.C. } \\
\text { Upper Three Runs near New Ellenton, S.C. } \\
\text { Brushy Creek near Wrens, Ga. } \\
\text { Big Sandy Creek near Jeffersonville, Ga. } \\
\text { Upatoi Creek near Columbus, Ga. } \\
\text { South Fork Cowikee Creek near Batesville, Ala. } \\
\text { Pataula Creek near Lumpkin, Ga. } \\
\text { Whitewater Creek below Rambulette Creek near } \\
\text { Butler, Ga. } \\
\text { Kinchafonee Creek at Preston, Ga. } \\
\text { Mackys Creek near Dennis, Miss. } \\
\text { Bull Mountain Creek near Smithville, Miss. } \\
\text { Buttahatchee River near Aberdeen, Miss. } \\
\text { Catoma Creek near Montgomery, Ala. } \\
\text { Big Swamp Creek near Lowndesburg, Ala. } \\
\text { Mulberry River at Jones, Ala. } \\
\text { Boguechitto Creek near Browns, Ala. } \\
\text { Coal Fire Creek near Pickensville, Ala. } \\
\text { Fivemile Creek near Greensboro, Ala. }\end{array}$ & $\begin{array}{l}1.55 \\
2.52 \\
1.85 \\
1.40 \\
1.35 \\
3.47 \\
1.43 \\
2.81 \\
3.57 \\
1.11 \\
1.49 \\
1.65 \\
1.64 \\
2.71 \\
1.48 \\
1.13\end{array}$ & $\begin{array}{l}\text { Sand. } \\
\text { Do. } \\
\text { Sand and some.clay. } \\
\text { Clayey sand. } \\
\text { Sand-sandy limestone. } \\
\text { Sand. } \\
\text { Sandy limestone. } \\
\text { Dense limest one clay } \\
\text { with sand veneer. } \\
\text { Sand. } \\
\text { Do. } \\
\text { Sand with clay veneer. } \\
\text { Sand. } \\
\text { Chalk-sand. } \\
\text { Sand. } \\
\quad \text { Do. } \\
\text { Sand-1imestone. } \\
\text { Sand-some clay. } \\
\text { Sand. } \\
\text { Do. } \\
\text { Chalk-some sand. } \\
\text { Do. } \\
\text { Sand. } \\
\text { Chalk-some clay. } \\
\text { Sand-some clay. } \\
\text { Do. }\end{array}$ \\
\hline
\end{tabular}

In order to use equation 5 , the distance " $a$ " to the ground-water divide must be known. Because "a" cannot readily be measured, a method of approximation used by Daniel (1976) and Johnston (1976) was followed. The distance " $a$ " was expressed in terms of drainage area as follows:

$\mathrm{a}=\mathrm{A} / 2 \mathrm{~L}$

where $A$ is the drainage area and $L$ is the length of perennial streams in the basin. This relation assumes a rectangular basin with the ground water discharging primarily to one perennial stream flowing down the middle of the basin. It also assumes that the ground-water divide coincides with the surface-water divide.

As Trainer and Watkins (1975) have pointed out, there are problems of interpreting base flow recessions from the hydrograph. "The brevity of most recession episodes makes the slope of the recession curves difficult to establish precisely."
Then, too, "losses from ground water and from streamflow above the gage through evapotranspiration distort the ideal recession curve during much of the year, and... many recession curves are complex because of the nonhomogenity of the aquifer." For these reasons, particularly the brevity of recessions, and because detailed topographic maps to provide information needed to calculate the distance " $\mathrm{a}$ " are not available for all of the watersheds, hydraulic diffusivities were not estimated for all 35 stations. Selected estimated hydraulic diffusivities are listed in table 3. Theoretically, each basin is associated with one recession slope but in actual practice the slopes may be different depending upon the interpreter. Several possible recession slopes are therefore presented for each station (see table 3 ). Recession slopes have previously been determined for Alabama streams (Bingham, 1982). These values were used along with analysis of the hydrographs to estimate slopes for stations 02442000 , 02443000 , and 02444000 . 


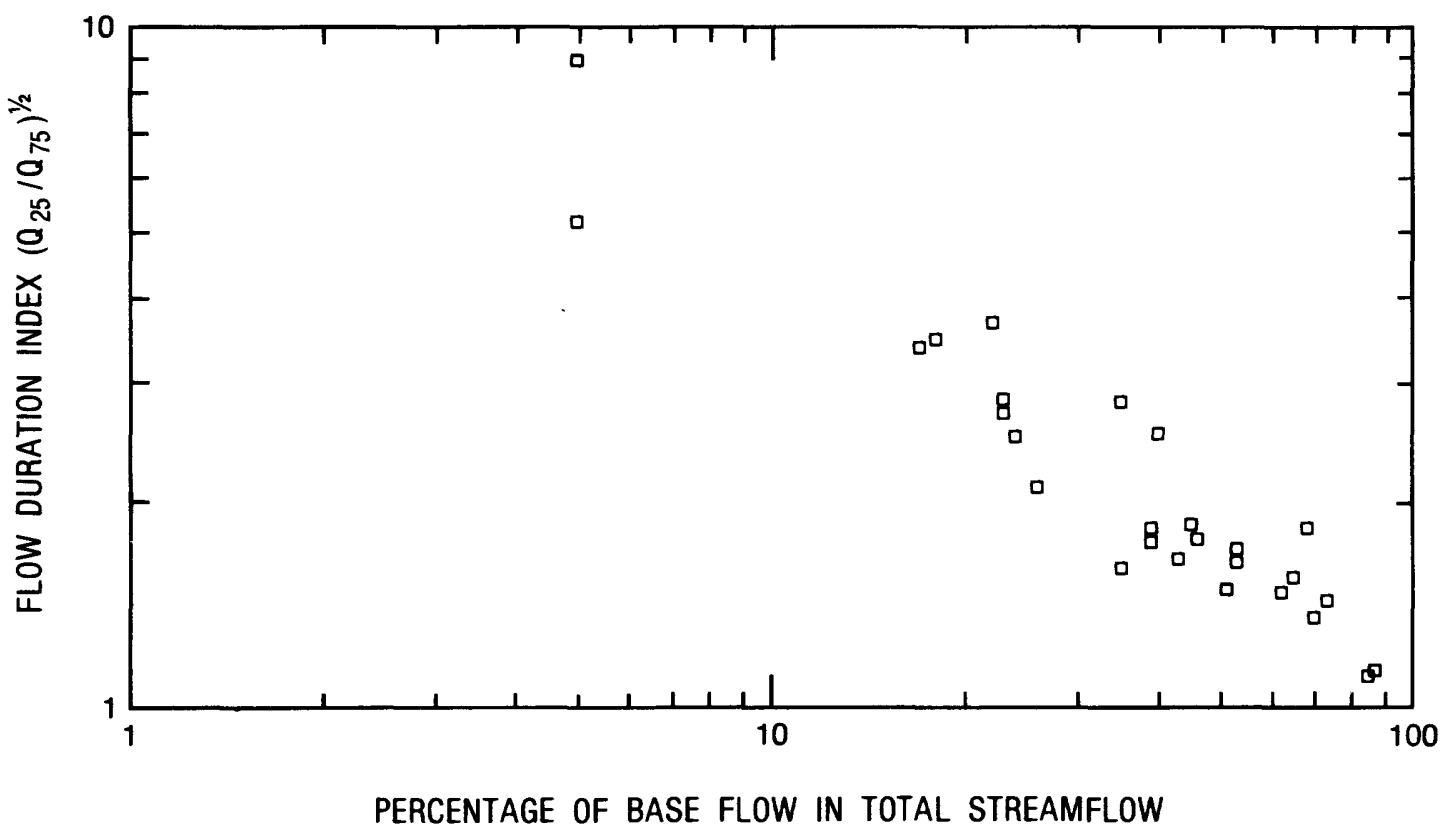

Figure 10. Comparison of flow duration index to percent of total streamflow that is base flow.

Because streams listed in table 3 drain an unconfined sand and gravel aquifer, specific yield rather than storage coefficient is applied to convert diffusivity to transmissivity. A specific yield of 0.15 was selected as reasonable for the area based upon values given in Linsley and Franzini (1972). Basin transmissivities $(T)$ were then calculated and are listed in table 3; for comparison, values of $\mathrm{T}$ from specific capacity well data, if available, are also listed in table 3.

Note, for those basins where field well data are available, the estimated transmissivities from streamflow recessions are comparable to the transmissivities from well data. Thus estimation of T's from streamflow data is a promising reconnaissance technique for the Coastal Plain sand aquifer in southeastern United States.

\section{SUMMARY AND CONCLUSIONS}

Minimum recharge rates to Coastal Plain sand aquifers were derived from base flows of rivers in the outcrop area. Streamflow hydrographs for 35 stations in or near the outcrop area were separated using base flow recession curves in a manner described by Riggs (1963). Hydrographs were separated for years when the annual mean flow was higher than, lower than, and close to the average mean flow for the period of record for each of the 35 stations. These values were then averaged to determine the mean annual base flow. Discharge at the 65-percent duration point on the flow duration curve was found to closely approximate mean annal base flow for 32 of the 35 streams examined. Discharge at the 60 -percent duration point on the flow duration curve was also found to be closely related. Therefore, either the 60 - or the 65 -percent duration flow may be used in the outcrop area in lieu of hydrograph separation as an approximation of mean annual base flow for those streams with mean base flows greater than $10 \mathrm{ft}^{3} / \mathrm{s}$.

Base flow recession curves were used to derive estimates of hydraulic diffusivity of the aquifer which was converted to transmissivity using estimated specific yield. These base flow derived transmissivities are in general agreement with transmissivities derived from well data.

The lithology of the Coastal Plain sediments is closely related to the shape of flow duration curves. Steep flow duration curves appear to be associated with basins underlain by clay or chalk where a low percentage of the discharge is base flow while flatter curves appear to be associated with basins underlain by sand and gravel where a high percentage of the discharge is base flow. 


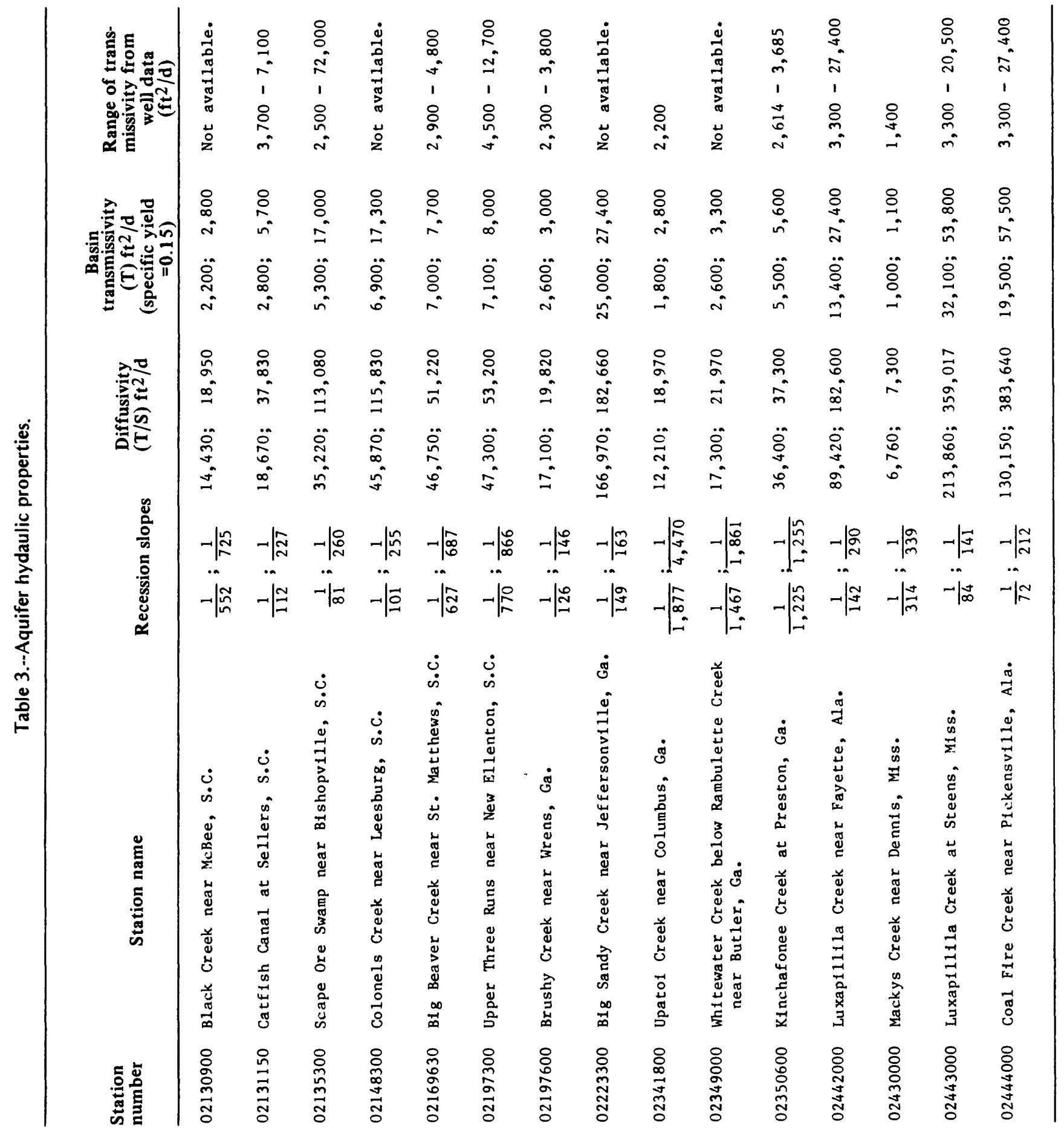




\section{REFERENCES}

Ackroyd, E. A., Walton, W. C., Hills, D. L., 1967, Ground-water contribution to streamflow and its relation to basin characteristics in Minnesota: Minnesota Geological Survey Report of Investigations $6,36 \mathrm{p}$.

Bingham, R. H., 1982, Low-flow characteristics of Alabama streams: U.S. Geological Survey Water-Supply Paper 2083, 27 p.

Cushing, E. M., Kantrowitz, I. H., Taylor, K. R., 1973, Water resources of the Delmarva Peninsula: U.S. Geological Survey Professional Paper 822, p. 33-35.

Daniel, J. F., 1976, Estimating ground-water evapotranspiration from streamflow records: Water Resources Research, v. 12, no. 3, p. 360-364.

Hall, F. R., 1968, Base-flow recessions--a review: Water Resources Research: v. 4, no. 5, p. 973-983.

Johnston, R. H., 1976, Relation of ground water to surface water in four small basins of the Delaware Coastal Plain: Delaware Geological Survey Report of Investigations No. 24, $56 \mathrm{p}$.

Linsley, R. K., and Franzini, J. B., 1972, Water Resources Engineering: New York, McGrawHill, Table 4-1, p. 85.

National Oceanic and Atmospheric Administration, 1981a, Climatological data annual summary, Alabama, v. 87 , no. 13 , p. 4-5.
$1981 b$, Climatological data annual summary, Georgia, v. 85 , no. 13 , p. 4-5.

$1981 c$, Climatological data annual summary, Mississippi, v. 86, no. 13, p. 4-5.

1981d, Climatological data annual summary, South Carolina, v. 84, no. 13, p. 3-4.

Pettyjohn, W. A., and Henning, Roger, 1979, Preliminary estimate of ground-water recharge rates, related streamflow and water quality in Ohio: Water Resources Center, Ohio State University, $321 \mathrm{p}$.

Reynolds, R. J., 1982, Base flow of streams on Long Island, New York: U.S. Geological Survey Water-Resources Investigations 81-48, $33 \mathrm{p}$.

Riggs, H. C., 1963, The base-flow recession curve as an indicator of ground water: International Association of Scientific Hydrology Publication 63, p. 352-363.

Rorabaugh, M. I., 1960, Use of water levels in estimating aquifer constants in a finite aquifer: International Association of Scientific $\mathrm{Hy}$ drology Publication 52, p. 314-323.

Trainer, F. W., and Watkins, F. A., Jr., 1975, Geohydrologic reconnaissance of the Upper Potomac River basin: U.S. Geological Survey Water-Supply Paper 2035, 68 p. 